\title{
Comparative Study of the Financial Independence, Self-Confidence and Decision-Making Power, Awareness of the Social Resources and Mental Health in the Women Members of SHG and Non-Member of SHG
}

\author{
Farhad Asghari ${ }^{1}$, Abbas Sadeghi ${ }^{1}$, Khaled Aslani ${ }^{2}$ \\ ${ }^{1}$ Department of Educational Sciences, University of Guilan, Rasht, Iran \\ ${ }^{2}$ Department of Counseling, University of Shahid Chamran, Ahvaz, Iran \\ Email: asadeghi_2003@yahoo.com
}

Received August $6^{\text {th }}$, 2012; revised October $7^{\text {th }}$, 2012; accepted October $21^{\text {st }}, 2012$

\begin{abstract}
The main objective of the present paper was the evaluation of the program of the self help groups in the Kurdistan, Kermanshah, Hamadan and Western Azerbaijan in Iran. The Casual-comparative research method has been used in this research and statistical population was all the women members of SHG and Non-Member of SHG. The statistical samples were included 289 the women members of SHG (137) and Non-Member of SHG (152) due to the size of the population, more than /90 of population has been selected. Three different research instrument have been used which are included Demographic features questionnaire, Questionnaire of the evaluation of the self help groups' empowerment, General Health Questionnaire (GHQ-28). The reliability of the questionnaire of the evaluation of the self help groups' empowerment was /80 and General health questionnaire (GHQ-28) was /92. According to the research results, there are significant relationship between the amount of the financial independence, self confidence, the decision making power and the amount of the awareness of women members of SHG and NonMember of SHG. Also, there were no significant relationship between the amount of cutting dependency to direct financial supports and mental health the women members of SHG and Non-Member of SHG.
\end{abstract}

Keywords: Financial Independence; Self-Confidence; Decision-Making Power; Social Resources; Mental Health

\section{Introduction}

The concept of feministic empowerment views needs more attention than concepts like economic situation and it includes women's welfare and strategic benefits (Swain, 2006). Feminists have also argued that the given women's primary responsibility for ensuring social reproduction, state policies that subsidize the costs of social reproduction are an important aspect of engendered development policy (Power, 2004). Another concept suggested by Sen (1999) which emphasizes on the effects of social empowerment, deals with some crucial matters like co-existence and survivorship which include appropriate nutrition, place of living and suitable hygiene. Regardless of lifestyle these are called the fundamental principles of life. Empowerment is a multilevel construct and there-fore, analysis of empowerment methods and outcomes should be directed at three interdependent levels. These three levels are: 1) individual or Psychological Empowerment (PE); 2) Community Empowerment (CE); and 3) Organizational Empowerment (OE) (Rappaport, 1984; Zimmerman et al., 1992; Israel et al., 1994; Zimmerman, 1995). Mayoux (2000) defines empowerment as a process of inside change, or inside power, improving capabilities and communal mobilization. The individual empowerment may be describes as appropriate decisions and improving auto- nomy and the control of their own economic resources. In definition of the empowerment he mentioned that the empowerment has a direct relationship with power as a polyhedral process which includes: power within: it enables women to express their wishes in detail and also it gives them strategies for expressing changes in their life. Power to: it enables women to improve the needed skills for achieving their wishes. Power with: it enables women to evaluate and expressing their interests to organize and achieve them and to think about other women and men's organizations. Power over: which includes changing the inequality of power and resources which influences women's wishes and enable them to achieve their wishes? The component of power incorporates different parts and levels of life. Kabeer (1999) emphasize that empowerment is a process that women deny their capability for making strategic decisions. Women who are in cooperative groups are completely safe by improving the feeling of self or Son. Empowerment helps women to understand identity, capabilities and power. It also helps the women to overcome shyness and to feel confidence whenever they talk about themselves (Umushankar, 2006). These groups have an impact on empowerment and improving efficiency by controlling the resources and recognition and self-respect (Zamman, 2001). Recently different studies about the positive effects of cooperative groups have been re- 
ported (Simanowitz \& Walker, 2002). Usually the main goal of these economical services in India is thriftiness, credibility and products of poor people in the village and urban areas to increase the rate of incomes and improving the standards of life (NABARD $\left.{ }^{1}, 2006\right)$. The result of Tomkha (2002) study about the socioeconomic situation of 560 members of 223 cooperative groups from 11 provinces before and after joining to the group showed that: the average possession of the family increases $72.3 \%$ and during three years it reached to 11,793 rupiah. The average net income also increases which was from different businesses by getting the loan. It is from 20,177 rupiah to 26,889 rupiah. The rate of employment growth has been 17 percent. Getting loan for doing business has an increase from 50 percent to 70 percent. 47.8 percent of the families are not below the poverty line anymore. The results of a study from cooperative women group in Tamil Nadu (2007) showed that a member who joins the group has cattle and properties and were in debt. And the age and the productive properties except the land have a negative independency with participation in the group. But social backwardness, being in debt and the need for the loan in the region or neighbor villages, has a positive effect on women contribution. The result of Anjogam and Rasmamy (2007) showed that the most popular reasons for joining to the group are, getting loan, doing business, saving money and reducing previous debts. Moreover Puhazhendi and Badatya (2002) in their studies of the cooperative groups found that this program has a positive social effect. Puhazhendi and Satyasai (2000) argued that the social effect of the cooperative groups' program is more than its economic effect. The results of Rao study (2008) on reforms with a female face showed that the latter lacks administrative support and relies upon the expenditure of time and resources by participants themselves, re-emphasizing class and caste inequalities among women and undermining the broader project of empowerment.

According to the results of Swain (2006) study, 88\% of the members reported that they feel more confidence after joining the group. They showed positive change in expressing their beliefs and activity, confidence and communication skills have been improved among them. Improving knowledge and contribution in local political organization and participation in the government political actions have been observed among the members of the cooperative groups. The main purpose of this article is to evaluate the cooperative groups and deals with economic independency, self-confidence, decision making, and familiarity with social resources in females headed households and mental health of Self-Help Groups (SHG) in Kurdistan, Kermanshah, Hamadan and western Azerbaijan Providences.

\section{Methodology}

The Causative-comparative approach has been used in this research. The research is about the women who members of self help groups and females who are not a member of self help groups which are under protection of welfare organization in the Hamadan, Kermanshah, Kurdistan, and Western Azerbaijan. Because the community and members of the self help groups under study were limited, most of them had been taken as an example. The members of the control group are similar to the self help group members in many areas like cultural, social, educational, economical situation, age and family.

${ }^{1}$ National Bank for Agriculture and Rural Development.
Demographic features questionnaire, Questionnaire of the evaluation of the self help groups' empowerment, General health questionnaire (GHQ-28).

Demographic features questionnaire: this questionnaire is about the population of the women who are a member of the SHG and who are not. The questions are about age, education, marriage, place of living, the numbers of the members of the family and the date of constitution which are provided by the researcher. Questionnaire of the evaluation of the cooperative groups' empowerment: this questionnaire provided by the researcher and based on 4 principles:

1) Evaluation of the economic independence;

2) Self-confidence and decision making;

3) Dependence and independence to direct economical support;

4) Recognition of the social resources.

This questionnaire is based on some other questionnaires presented by Baland et al. (2008), Basu and Srivastava (2010), Swain (2006), which were about the evaluation of the empowerment of the cooperative groups. This questionnaire has been confirmed by sociologists and psychologists. The calculated durability of the questionnaire is based on the Cronbach alpha factor which is 80 .

General health questionnaire firstly conducted by Goldberg (1972). This test evaluates the illness factors, one month before taking the exam. Golberg first calculated the rate of GHQ and then reported that the rate of sensitivity, specifity and the error factor in a category of 60 questions are $77.5 \%, 88.4 \%$ and $15.4 \%$ respectively. These GHQ results in Iran are $86.5 \%$, 82\% and 16\% (Vaghobi, 2008). The results of Gibones et al. (2004) study using test-retest approach are alpha coefficient/74. According to the cutting point which is 6.7 , the sensitivity is 88 and specifity is 84.2. In Palaheng (1997) study in which the cutting point is 22 , the sensitivity, specify, category error, is: 88 , 74, 80, 20 and the alpha coefficient in present study is $/ 92$.

\section{Findings}

As we see in Table 1, the average and standard deviation related to the Member of SHG and Non-Member of SHG are described.

Table 2 shows the one way variance analysis of variables economic independence, self-confidence \& decision-making power, Cutting dependency to direct supports, Knowledge of social resources and Mental health in members of SHG and Non-Member of SHG.

\section{Discussion and Conclusions}

Evaluation of the results of the first hypothesis showed that: "there is a huge difference between in the financial independency of the self headed females who are a member of SHG and who are not." The result of this research is similar to the results of the Microfinance Innovation Department researches (2002), Meyer and Tenkha (2002), Basu (2006) and Tamil Nadu (2007). The results of the Microfinance Innovation Department researches (2002) show that the sample members reported a 59 percent increase of their properties. Their living conditions get better and they learned to save money. The results of Meyer and Tankha's study (2002) showed that the social condition of 560 members of 223 cooperative groups from 11 provinces has a 72.3 growth in the family possessions after joining to the 
Table 1.

Comparisons between member and Non-Member of SHG.

\begin{tabular}{|c|c|c|c|c|}
\hline Variables & Groups & $\mathrm{NO}$ & Means & $\begin{array}{l}\text { Standard } \\
\text { deviation }\end{array}$ \\
\hline \multirow{2}{*}{$\begin{array}{l}\text { Economic } \\
\text { independence }\end{array}$} & Members of SHG & 137 & $12 / 45$ & $1 / 88$ \\
\hline & Non-Members of SHG & 162 & $11 / 26$ & $2 / 77$ \\
\hline \multirow{2}{*}{$\begin{array}{c}\text { Self-esteem \& } \\
\text { decision-making } \\
\text { power }\end{array}$} & Members of SHG & 137 & $16 / 37$ & $2 / 52$ \\
\hline & Non-Members of SHG & 162 & $14 / 86$ & $2 / 80$ \\
\hline \multirow{2}{*}{$\begin{array}{l}\text { Cutting dependency } \\
\text { to direct supports }\end{array}$} & Members of SHG & 137 & $20 / 15$ & $3 / 57$ \\
\hline & Non-Members of SHG & 162 & $20 / 04$ & $3 / 06$ \\
\hline \multirow{2}{*}{$\begin{array}{l}\text { Knowledge of } \\
\text { social resources }\end{array}$} & Members of SHG & 137 & 7/94 & $1 / 65$ \\
\hline & Non-Members of SHG & 162 & $6 / 22$ & $2 / 54$ \\
\hline \multirow{2}{*}{ Mental health } & Members of SHG & 137 & $26 / 98$ & $11 / 38$ \\
\hline & Non-Members of SHG & 162 & $25 / 61$ & $12 / 30$ \\
\hline
\end{tabular}

Table 2.

The one way variance analysis of variables economic independence, self-confidence \& decision-making power, cutting dependency to direct supports, knowledge of social resources and mental health in members of SHG and Non-Member of SHG.

\begin{tabular}{ccccccc}
\hline V & Errors & Sum of S & D.F & M.S & F & S.L \\
\hline \multirow{4}{*}{ E.I } & B.G & $104 / 27$ & 1 & $104 / 27$ & & \\
& I.G & $1728 / 58$ & 297 & $5 / 82$ & $17 / 92$ & $0 / 000$ \\
& Total & $1832 / 85$ & 298 & & & \\
& B.G & $168 / 14$ & 1 & $168 / 14$ & & \\
S \& D-M-P & I.G & $2135 / 83$ & 297 & $7 / 91$ & $23 / 38$ & $0 / 000$ \\
& Total & $2302 / 97$ & 298 & & & \\
& B.G & $0 / 951$ & 1 & $0 / 951$ & & \\
CD to DS & I.G & $3239 / 04$ & 297 & $10 / 91$ & $0 / 087$ & $0 / 768$ \\
& Total & $3239 / 99$ & 298 & & & \\
& B.G & $218 / 81$ & 1 & $218 / 81$ & & \\
K of SR & I.G & $1407 / 26$ & 297 & $4 / 74$ & $46 / 18$ & $0 / 000$ \\
& Total & $1626 / 08$ & 298 & & & \\
& B.G & $139 / 32$ & 1 & $139 / 32$ & & \\
M.H & I.G & $41980 / 4$ & 297 & $141 / 35$ & $0 / 986$ & $0 / 323$ \\
& Total & $42119 / 7$ & 298 & & & \\
\hline
\end{tabular}

Note: $\mathrm{V}$ = Variable; E.I = Economic Independence; S \& D-M-P = Self-confidence \& Decision-Making Power; CD to DS = Cutting Dependency to Direct Supports; K of SR = Knowledge of Social Resources; M.H = Mental Health; B.G = Between Groups; I.G = Inter Groups; Sum of S = Sum of squares; M.S = Mean of Squares; S.L = Significance Level.

cooperative group. A study in India on cooperative groups in 4 province showed that $36 \%$ members saved less than 30 rupiah in a month, $51 \%$ of them 31 - 50 rupiah and $13 \%$ saved more than 50 rupiah in a month. And for all the groups the savings were about 33,700 rupiah in a year (Basu, 2006). Another study carried out in Tamil Nadu. According to its results the family who joined the group posse's cattle and properties although this family had huge debts before joining to the group.

The results of the second hypothesis showed that there is a huge difference in the rate of self-confidence between the self headed females who are a member of the cooperative group and who are not. The results are similar to Anjugam and Ramasamy (2007), Puhazhendi and Badatya (2002), Puhazhendi and Satyasai (2000) and Swain (2007) according to the results of An- jugam and Ramasami (2007), the social condition of the self help groups members got better after joining to the self help group. Moreover the dependency to lenders who are out of group was decreased. Puhazhendi and Satyasai (2000) argued that the social effects of cooperative groups' programs are more than its economical effect. Self help groups have an important role in reduction of vulnerability of the poor people and help them to work and make money. The results of the Swain (2007) study showed that $88 \%$ of the members of the cooperative groups reported a self-confidence improvement.

After studying the third hypothesis "there's a huge difference between the independence of self headed females who are a member of the self help groups and self headed females who are not." The result was just the opposite. The results of this study were in contrast with findings of Haris (2007), Basu (2006), Puhazhendi and Satyasay (2000), Mont Gomry and colleagues (1999), the organization of economic development, rural system (2006) and Aisha Khan (2006). Another study carried out by Puhazhendi (2000) between the years of 1996-1997. It was about the cooperative groups' performance. He found that $61 \%$ of the members had an acceptable performance, $29 \%$ had a normal performance and $10 \%$ had a weak performance. Another study carried out on 12 rural development committee in Bangladesh. $10 \%$ of the women reported that they have no income and they get help from their friends and family (Mont Gomery et al., (1996). Another research in India about self help groups had been conducted. It studied 214 cooperative groups in 108 villages in 4 provinces and 9 crowded regions. Consequently these groups were economically and socially successful (Rural Education and Action Development, 2006). Also Aisha Khan (2006) believes in the positive effects of cooperative groups. More than 90 percent of cooperative groups in Iran get pension from welfare organizations and they also do some economical activities however, most of the self help groups have no saving fund and they make money by some economical activities although it is in contrast with the principles of the cooperative groups. It seems that cooperative groups in Iran, who are financially independent, hide their independency. Because the governmental organization might stop their financial support.

The fourth hypothesis there is a meaningful difference between the social resources of the women who are member of the self help groups and who are not. In Table 2 the results show that there is no meaningful difference between them. The results of this hypothesis are similar to the results of Letil Field and his colleagues research (2003).

A study carried out by the National Institution of Rural Development in the year 2004, showed that $57 \%$ contribute in programs. $82 \%$ of the members said that they send their children to school. $43 \%$ of the members have got loans. It showed women contribution in making decisions (Rao et al., 1999). Harper's study (1998) on 1000 members of the cooperative groups in 4 provinces showed that nutrition diets, properties and level of education had been improved. The members get benefits in different levels but for poor families it is a little harder. Just $31 \%$ of members of the poor families improve their properties and $15 \%$ improve their educational condition.

In the fifth hypothesis "there is a meaningful difference between the mental health of the women who are a member of the self help groups and women who are not. According to the results of Table 2, the hypothesis disproved. There's no available research that specifically studies the relationship between the self help groups and mental health. In Swain (2006) study there was a huge difference between the answers of the self- 
help group and control group. 88\% of the respondents reported a increased rate of reliance after joining to the group. And they feel more positive changes in expressing their opinion. Basu and Vastava (2010) regard the increased rate of self-respect and welfare as the effects of the cooperative groups.

The results of the Meyer and Tankha (2002) show that the positive effects of the self help groups on the members are: self-confidence, communication skills, participation in social oppositions, logical responses to problems and reduction of aggression. Poverty reveals the story of women and their pressures and endeavors. Poverty causes low self-confidence, pressure and dependency and limit capacities and participation in self help groups leads to a change. Women show the "feeling of freedom”, increase their self-respect and self-confidence, their understandings change and the feeling of power and motion have its roots in limitation and force.

We should pay attention that where the mental health of the women is not normal. It helps to choose the women for the self help groups. women who are under pressure because of different reasons such as death of husband, disease, husbands breakdown, disease of other members of the family, poverty and financial problems, lack of control in life, lack of basic skills, lack of social and family support, feeling of loneliness, absence of sufficient mental and physical services and absence of psychologists and chronic mental and physical disease.

\section{REFERENCES}

Aisha Khan (2006). Women self-help groups in Andhra Pradesh. Poverty to prosperity. Self-help groups: Use of modified roscas in microfinance. First draft.

Anjugam, M., \& Rasmamy, C. (2007). Determinants of women's participation in self-help group (SHG)-Led Microfinance Programme in Tamil Nado. The IDEAS, 20.

Baland, J. M., Somanathan, R., \& Vandewal, L. (2008) Microfinance life spans: A study of attrition and exclusion in self-help groups in India. The IDEAS, 4, 159-210.

Basu, P. (2006). Microfinance and women empowerment-An empirical study with special to West Bengal. West Bangal: Ruje Peary Mohan College.

Basu, P., \& Srivastava, P. ( 2010). Scaling-up microfinance for India's rural poor. Washington DC: World Bank Policy Research Working Paper 3646.

Goldberg, D. P. (1972). The detection of psychiatric illness by questionnaire. London: Oxford University Press.

Goldberg, D. P., \& Hillier, V. F. (1979). A scaled version of general health questionnaire. Psychological Medicine, 9, 131-145. doi:10.1017/S0033291700021644

Gibbons, P., Arevalo, H. F., \& Monico, M. (2004). Assessing of the factor structure and reliability of the 28 item versions of the General Health Questionnaire (GHQ-28) in Salvador. International Journal of Clinical Health Psychology, 4, 389-398.

Harris, S. (2004). State of the Microcredit Summit Campaign Report.

Harper, M. (1998). Profit for the poor-Cases in microfinance. New Delhi: Oxford and IBH Publishing Co., Ltd.

Israel, B. A., Checkoway, B., Schulz, A., \& Zimmerman, M. (1994). Health education and community empowerment: Conceptualizing and measuring perceptions of individual, organizational and community control. Health Education Quarterly, 21, 149-169. doi: $10.1177 / 109019819402100203$

Kabeer, N. (2001). Conflicts over credit: Re-evaluating the empowerment potential of loans to women in rural Bangladesh. World Development, 29, 63-84. doi:10.1016/S0305-750X(00)00081-4

Kabeer, N. (1999). Resources, agency, and achievements: Reflections on the measurement of women's empowerment. Development and Change, 30, 435-464. doi:10.1111/1467-7660.00125

Mayoux, L. (2000). Micro credit and the empowerment of women: A review of the key issues. Social Finance Unit Working Paper, Geneva.

Mont, G. R., Bhattacharya, D., \& Hulme, D. (1996). Credit for the poor in Bangladesh. In D. Hulme, \& P. Moseley (Eds.), Finance against poverty. London: Rutledge.

NABARD (2006). National bank for agriculture and rural development. Annual Report, 2005-2006. Mumbai.

www.nabard.org, 2006

Palahang, H. (1997). Epidemiology of mental health in kashan urban area. Thesis of Masters, Tehran: Iran Medical University.

Power, M. (2004). Social provisioning as a starting point for feminist economics. Feminist Economics, 10, 3-19. doi:10.1080/1354570042000267608

Puhazhendi, V., \& Badatya, K. C. (2002). Shg-bank linkage programme for rural poor-An impact assessment. New Delhi: SHG-Bank Linkage Programme Seminar.

Puhazhendi, V., \& Satyasai, K. J. S. (2000). Microfinance for Rural People: An Impact Evaluation. Study Report, Mumbai: Nabard.

Rappaport, J. (1984). Studies in empowerment: Introduction to the issue. Prevention in Human Services, 3, 1-7.

Rao, D. S. R. P., Satish, G. S., \& Chauhan, D. S. (1999). Study or shgs as financial interviediaries. Working Paper No. 15, New Delhi.

Rao, S. (2008). Reforms with a female face: Gender, liberalization, and economic policy in Andhra Pradesh, India. World Development, 36, 1213-1232. doi:10.1016/j.worlddev.2007.06.020

Sen, A. K. (1990). Gender and cooperative conflicts. In I. Tinker (Ed.), Persistent inequalities (pp. 123-149). New York: Oxford University Press.

Sen, A. (1999). Development as freedom. New York: Alfred A Knopf.

Swain, B. S. (2006). Can microfinance empower women? Self-help groups in India. Ada Dialogue, 37, 37-42.

Simanowitz, A., \& Walker, A. (2002). Ensuring impact: Reaching the poorest while building financially self-sufficient institutions, and showing improvement in the lives of the poorest women and their families. URL (last checked 10-13 November 2002). http://www.microcreditsummit.org/papers/papers.html/

Tamkha, A. (2002). Self-help groups as financial Intermediaries in India cost of promotion, sustainability and impact. New Delhi: Sa-Dhan.

Umashankar, D. (2006). Women's empowerment: Effect of participation in self-help groups. Dissertation Submitted in Partial Fulfillments of Requirements for the Post Graduate Program in Public Policy and Management. Indian Institute of Management Bangalore.

Yaghobi, H., Ghaedi, G., Omidi, A., Kehani, S., \& Masood, Z. (2008). Primary study of reliability and determination of GHQ-12 and GHQ28 on students of Shahed University. Shiraz: Seminar on Mental Health of Students.

Zamman, H. (2001). Assessing the Poverty and Vulnerability Impact of Microcrediting Bangladesh: A Case Study of BRAC. World Development Report 2000-2001, Washington DC: World Bank.

Zimmerman, M., Israel, B., Schulz, A., \& Checkoway, B. (1992). Further explorations in empowerment theory: An empirical analysis of psychological empowerment. American Journal of Community Psychology, 20, 707-727.

Zimmerman, M. (1995). Psychological empowerment: Issues and illustrations. American Journal of Community Psychology, 23, 581-599. 